\title{
CONSUMER BEHAVIOUR FORMATION IN THE CUSTOMIZED SERVICE MARKETS: A CASE OF UKRAINE
}

\author{
Victoria Zhurylo ${ }^{1}$, Olga Prygara ${ }^{2}$ \\ Taras Shevchenko National University of Kyiv, Ukraine
}

\begin{abstract}
Targetsetting. In modern conditions, in some markets for goods in mass demand, companies are increasingly beginning to introduce customization in marketing activities, which involves the implementation of marketing tools aimed at ensuring a wide differentiation of the trade offer, the establishment of direct communication with the target audience, which provides an opportunity to attract the consumer to the production of goods and to adjust product under its certain requirements. Uninvestigated parts of general matters defining. The study of the market behaviour of consumers is a branch of knowledge that is rapidly and dynamically developing and falls within the scope of scientific interests of a large number of scientists. The emphasis in existing studies of consumer market behaviour is made on the study of commodity markets. There are publications devoted to questions of consumer behaviour research in the service markets, but there are practically no publications on the study of behavioural patterns in service markets on an orderly basis. The purpose of the article is to study features of the market behaviour of consumers on the Ukrainian market of exclusive confectionery products to order. Methodology. The authors of the article conducted a marketing research on the motivation and behaviour of consumers on the Ukrainian market of exclusive confectionery products to order. The sample comprised 117 people, of which $71 \%$ of the respondents were women, $29 \%$ of respondents were men. The statement of basic materials. The main purchasing motives of the consumer who decides to order exclusive confectionery products are investigated and it is revealed that the ordered product is characterized by a high level of emotional consumer value. The description of the customer's motivation field is presented and consumer risks, which influence the market behaviour of consumers of exclusive desserts, are viewed. According to the results of the study, such existing areas of dissatisfaction of target consumers are identified, namely, design mismatch expectations, unjustified prices, dissatisfaction with taste, the inconsistency of packaging, complex order procedure, which requires time and effort. Conclusions. Using the results of the conducted marketing research, recommendations for producers of exclusive desserts to reduce possible dissatisfaction of the consumer when ordering exclusive desserts are presented. First of all, manufacturers should try to provide as much as possible a clear description of the offered services, try to visualize and materialize the offer to the consumer, thus reducing his perceived risks.
\end{abstract}

Key words: consumer behaviour, buying process, information search, customization.

JEL Classification: D12, D91, D83, LI1

\section{Introduction}

The current stage of socio-economic development of our society is characterized by the tendency to individualize the process of consumption in certain commodity markets and services markets. The high intensity of globalization processes and increased competition lead to certain transformational phenomena in the market and information environments, in which the modern consumer is overwhelmed by market information, faces the problem of choosing markets for mass-market products, "tired" from "faceless" goods and complicated choices. This leads to increased consumer demands, the appearance of significantly higher queries regarding the qualitative characteristics of the product, design, ergonomic and aesthetic indicators, the need for individual service. In some markets for goods in mass demand, companies are increasingly beginning to introduce customization in marketing activities, which involves the implementation of marketing tools aimed at ensuring a wide differentiation of the trade offer, the establishment of direct communication with the target audience, which provides the opportunity to attract the consumer to the production of goods and to adjust product under its certain requirements.

Corresponding author:

${ }^{1}$ International Economics and Marketing Department, Taras Shevchenko National University of Kyiv.

E-mail: vikzhur@gmail.com

${ }^{2}$ International Economics and Marketing Department, Taras Shevchenko National University of Kyiv.

E-mail: olgaprygara@gmail.com 


\section{Review of theory and literature}

Recently, the study of the market behaviour of consumers is a branch of knowledge that is rapidly and dynamically developing and falls within the scope of scientific interests of a large number of scientists. During the last decades, a large number of scientific and practical works devoted to this topic have been published. This interest is primarily due to the fact that the problem of market behaviour of consumers is a key issue in marketing activities of companies since the realization of its economic interests directly depends on the company's ability to predict the actions of the target audience and to influence consumer decisions through the use of communication strategies and marketing tools. Among the main areas of consumer behaviour research, which reflect the modern approaches and aspects studied by scientists in previous centuries, including the position of marketing concept, one can distinguish the following: consumer behaviour studies in the classical economic theory, where the focus is done on clarifying the causes economic decisions of a person (A. Smith, D. Ricardo, H. Gossen, K. Menger); research of the decision-making process by the consumer under the influence of a set of incentive incentives: marketing, situational, psychological, environmental factors (F. Kotler 1999, 2005, 2008, J. Engell, R. Blackwell, P. Miniard 2006, Michael R. Solomon 1992, David A. Statt 1997, G. Foxol); formation of the concept of "demonstrative consumption" as a social phenomenon from the standpoint of socio-economic stratification of society (T. Veblen 1899, G. Simmel 1905, J. Baudrillard 1970, P. Bourdieu 2000, A. Toffler 2006); studying the impact of cultural aspects and gender factors on consumer behaviour (P. Lunt, S. Livingstone 1992, H. Dittmar 1995); research on the influence of mass communication on consumers, the impact of advertising on consumer behaviour (R. Cialdini 2005, A. Pratkanis 2007, E. Aronson 2001, D. Ogilvy 1983); the formation of the concept of "behavioural economics", in which, with the help of experimental methods, human behaviour is investigated in conditions of uncertainty, which proves that irrational behaviour of a person is not accidental, it is predictable (D. Kahneman 2000, A. Tversky 1982, 2000, P. Slovic 1981, 2007, D. Ariely 2010). Consequently, the degree of development of the problem is characterized by a rather high level and indicates its relevance and urgency for economic science and society.

Consumer market behaviour is the human activity associated with the selection, acquisition, and consumption of products or services to meet the current needs. Being on the market, the consumer goes through certain stages, namely: awareness of the need, seeking information on possible options for satisfying it, offered in the market, assessing existing market alternatives, buying decisions and consumer reaction to the purchase, which is to evaluate the used product based on the feeling his satisfaction.

It is becoming more popular in Ukraine to buy exclusive confectionery products for a present and order them on own holidays, this trend contributes to the rapid growth of demand in this market and activates the marketing activities of companies serving this segment. The aim of this article is to study the features of the market behaviour of consumers in the Ukrainian market of exclusive confectionery products and describe the stages of the buying process such as need recognition, information search, alternatives evaluation, purchase decision, and post-purchase behaviour.

\section{The statement of basic materials}

The authors of the article conducted a marketing research on the motivation and behaviour of consumers on the Ukrainian market of exclusive confectionery products to order. The sample comprised 117 people, of which $71 \%$ of the respondents were women, $29 \%$ of respondents were men. The sample was formed on an occasional basis: different types of consumers took part in the survey - those who had already ordered confectionery products earlier, and those who never had such experience; those who like sweets and constantly buys it, and those who absolutely do not feel the tendency to consume desserts but consider such a purchase as a gift or element of a desert. Let's consider the details of each of the stages of the consumer buying process: need recognition, information search, evaluation of market alternatives, purchase decisions, and after-purchase evaluation.

\section{Need recognition}

According to the results of the study, the main consumer motives of the consumer who decides to order exclusive confectionery products is the desire to make a lovely one, raise your mood, have fun, impress guests. About $85 \%$ of respondents said that they ordered a dessert not for personal consumption, but for a gift to their loved ones, colleagues, friends, family holidays or celebrities. The customer pays for the emotional reaction of the person who receives this gift, and even more - for the emotional satisfaction of this reaction. Consequently, the ordered product is characterized by a high level of emotional consumer value, which indicates a special attention of the customer and his high involvement in the purchasing process. Let's analyse the concept of value orientations of consumers in the market under study by M. Rokeach [1], in which the researcher proposes to consider the values of two types: terminal and instrumental. Terminal values are a person's conviction of the goals and ends of the world, to which he aspires, namely happiness, wisdom, freedom, and so on. Instrumental values relate to representations about desirable behaviours aimed at 
achieving terminal values (honesty, responsibility, courtesy, etc.). Table 1 provides instrumental and terminal values that are inherent to consumers based on the results of the study.

Consequently, the consumer's motivation field consists of the following main motives:

- the motive of satisfaction with the pleasure of relatives and close people. From $68 \%$ to $76 \%$ of consumers get pleasure from showing their attention to their relatives and observing their emotional response;

- the motive of the product usefulness and safety of consumption. From 46 to $54 \%$ of consumers are confident that exclusive confectionery products do not contain artificial flavours, GMOs, and other harmful ingredients;

- the motive of belonging to a certain group of people who make individual orders and do not consume mass-market products. From 46 to $56 \%$ of the target audience associate themselves with a group of people who are aesthetes, have a good taste, can afford to order exclusive desserts;

- the motive of freedom and creativity. From 24 to $36 \%$ of consumers like to have the freedom to choose, realize their own vision of the product, and not be limited in their choice;

- epistemic motive. From 24 to $36 \%$ of consumers believe that the order process is associated with the expectations of novelty and new emotions, they try to taste something new and special.

\section{Information search}

After the realization of the needs, the consumer faces a choice: where to order an exclusive dessert, which sources to attract to find the necessary information, where to start? Therefore, the next stage in consumer behaviour is Information search - it is a motivated process of activating a consumer of knowledge stored in his memory (internal search) or acquiring information from external sources (external search). It is not always the consumer who needs external search, sometimes he has enough internal searches to make a purchasing decision, during which there is indirect and direct internal search activity. Indirect internal search activity is carried out when the consumer extracts from memory that knowledge that was unconsciously incorporated into his long-term memory. Direct internal search activity occurs when the consumer deliberately extracts from the memory information related to a specific problem.

The need to attract all possible sources of information and components of a search depends on a number of factors: the existence of a customer's already established pattern of behaviour, the loyalty to a particular manufacturer/brand/product, the individual's propensity to innovate and the desire to taste something new, consumer experience and satisfaction/ dissatisfaction with the previous orders and so on.

We have determined that in the investigated market the consumer does not always turn to the external search, but always first turns to his own experience of solving the existing problem, then to the memories of the experience of friends and only later - to the external search. The majority of respondents ( $87 \%$ of respondents) noted that the positive past experience of cooperation with a certain confectionery manufacturer on request was a key factor in encouraging them to re-order and save time and effort in solving the problem. Nevertheless, certain respondents (36\%) noted that after 5-6 orders from the same manufacturer and being satisfied with the quality of the product and service, they are thinking about finding another confectionery, trying

Table 1

The scale of the value of target consumers of exclusive confectionery products to order

\begin{tabular}{|c|c|}
\hline Instrumental Values & Terminal Values \\
\hline $\begin{array}{l}\text { High queries: the desire to get a quality product with a } \\
\text { special, unique design for the appropriate fee. }\end{array}$ & $\begin{array}{l}\text { The happiness of others: when ordering exclusive desserts, a person gets emotional } \\
\text { satisfaction precisely because this product brings pleasure and joy to others - those } \\
\text { to whom he was appointed as a present or guests on his own holiday. }\end{array}$ \\
\hline Feelings, caring: the desire to make pleasure to relatives. & $\begin{array}{l}\text { Life in beauty (the beauty of art): special desserts are ordered by aesthetes, } \\
\text { who understand its value as a work of art, not just as a combination of } \\
\text { confectionery ingredients. }\end{array}$ \\
\hline $\begin{array}{l}\text { Creativity: an opportunity for the consumer to prove } \\
\text { himself through the order of an exclusive dessert, } \\
\text { something absolutely unique. }\end{array}$ & $\begin{array}{l}\text { Health: A person orders a high-quality dessert, in which only natural } \\
\text { ingredients are used because they are aware of the value of such foods for their } \\
\text { health and the health of their family. }\end{array}$ \\
\hline $\begin{array}{l}\text { Ability to love: ordering a product as a manifestation of } \\
\text { love for a loved one. }\end{array}$ & $\begin{array}{l}\text { Public recognition: In fact, the consumption of an exclusive dessert takes place in } \\
\text { the environment of other people and in fact is demonstrative. A person is pleased } \\
\text { when the people approve of such a choice of product, make compliments on this } \\
\text { account, want to follow the example, are interested in the manufacturer. }\end{array}$ \\
\hline $\begin{array}{l}\text { Rationalism: It's rational to spend a certain amount of } \\
\text { money on a quality product that is made from natural and } \\
\text { safe ingredients. }\end{array}$ & $\begin{array}{l}\text { An interesting life: a person seeks to diversify his own life, seeks to receive new } \\
\text { emotions even in everyday consumption and to make certain moments in his } \\
\text { life special. }\end{array}$ \\
\hline $\begin{array}{l}\text { Courage: the ability to dare for something unusual, try } \\
\text { something new, risk and experiment with taste and design. }\end{array}$ & $\begin{array}{l}\text { Cognition: exclusive desserts are every time absolutely new emotions, the } \\
\text { search for new tastes and designs. }\end{array}$ \\
\hline
\end{tabular}

Source: compiled by the authors on the results of marketing research 
to get "something new and interesting." Consequently, according to the results of the study, the following factors were identified, which determine the need for additional information:

1) consumer loyalty to a brand, which is formed under the influence of high emotional commitment of customers and a high level of satisfaction with the previous order and service;

2) the quality of existing knowledge and the availability of information that directly affects whether the consumer will base his choice only on internal search or still decides to supplement the lack of knowledge by external search;

3) time factor, in the situation when a pre-order was made by the consumer for a long time, therefore, he is not sure that the quality of products is still maintained at the proper level and the confectionery will be able to satisfy all its requirements;

4) the degree of involvement of the consumer in the process of solving the problem, which is mainly determined by the personal significance for the customer as much as possible to meet the existing needs and, accordingly, determines the level of motivation;

5) the individual's willingness to change the manufacturer and try new tastes.

There are two groups of specific factors influencing the external search for information that can lead to an increase or weakening of the user's search activity situational and individual factors. Table 2 provides a comprehensive matrix of factors of influence on the search for external information on the purchase of exclusive confectionery products.

\section{Evaluation of market alternatives}

Before taking a final decision in favour of a particular brand, the consumer always assesses existing market alternatives by applying a particular consumer choice strategy. The rules for making consumer decisions are divided into two groups: compensation rules that provide consumer compensation for the low level of some attributes of the product due to the high level of other attributes and non-compensation, which does not allow compensation of low ratings of one attribute with high estimates of another attribute. We have determined that a significant proportion of consumers ( $82 \%$ of respondents) of exclusive confectionery products make a purchasing decision using a noncompensated consumer choice model. They choose exclusive desserts precisely because of the criterion of exclusivity (peculiarities, individuality, specificity), which are not ready to yield, even if other attributes of goods are highly appreciated.

Among the non-compensation rules, in our opinion, the target consumer's behaviour is characterized by a disjunctive decision rule when the consumer has the minimum requirements only for the most significant criteria. That is, the consumer shares all attributes of the

Table 2

The matrix of factors influencing the search for external information by the consumer of exclusive confectionery products

\begin{tabular}{|c|c|c|}
\hline \multirow{2}{*}{ Direction of influence } & \multicolumn{2}{|c|}{ Influencing factors } \\
\hline & Situational factors & Individual factors \\
\hline $\begin{array}{l}\text { Increasing search } \\
\text { activity }\end{array}$ & $\begin{array}{l}\text { - social pressure from the surrounding and friends who } \\
\text { buy confectionery products on an individual order; } \\
\text { - high price of the product - confectionery products } \\
\text { on an exclusive order are more expensive than usual } \\
\text { products; } \\
\text { - intense competition in the market and a high level of } \\
\text { differentiation of the product offer, which complicates } \\
\text { the choice of potential consumers; } \\
\text { - clear competitive positioning by the criterion } \\
\text { of a special product group, which distinguishes } \\
\text { confectionery products on request from mass-market } \\
\text { products. }\end{array}$ & $\begin{array}{l}\text { - high level of consumer involvement as a consequence } \\
\text { of the special significance of the purchase; } \\
\text { - satisfaction with the process of knowledge, opening of } \\
\text { new opportunities when ordering desserts; } \\
\text { - satisfaction directly from the process of ordering a } \\
\text { product, tasting ingredients, developing your own } \\
\text { design; } \\
\text { - focusing on the health benefits of consuming products } \\
\text { made of high quality and natural ingredients; } \\
\text { - belonging to a particular social group that consumes } \\
\text { exclusive goods. }\end{array}$ \\
\hline $\begin{array}{l}\text { Weakening search } \\
\text { activity }\end{array}$ & $\begin{array}{l}\text { - lack of time in search for market information; } \\
\text { - influence of a competent specialist / recommendation } \\
\text { of friends; } \\
\text { - complexity of obtaining market information (low level } \\
\text { of communication activity of existing manufacturers). }\end{array}$ & $\begin{array}{l}\text { - high affection for a particular brand (unwillingness to } \\
\text { look for something new if there is a confectioner that } \\
\text { fully meets the requirements of the consumer); } \\
\text { - lack of knowledge about the subtleties of the } \\
\text { technological process of manufacturing products } \\
\text { and the possibilities / restrictions of manufacturers } \\
\text { specializing in individual orders; } \\
\text { - low level of involvement of the consumer in the } \\
\text { process of purchase. }\end{array}$ \\
\hline
\end{tabular}

Source: compiled by the authors on the results of marketing research 
product on essentially important and secondary, and considers only those variants, which receive from it the best estimation according to certain dominant attributes. Thus, even the best positions of the alternative option for non-dominant attributes are not taken into account at all, because it does not compensate for the insufficient level of the dominant attribute.

According to the research, it was determined that the customer of exclusive desserts is motivated by such key attributes of the product as the exclusive design, taste and naturalness of the ingredients used. Although among these characteristics of the product in the vast majority of respondents the design predominates, and the position in the rating of the significance of the attributes of the taste and the naturalness of the ingredients varies. It is determined that there are a number of biased attitudes and beliefs among target consumers:

- the first, exclusive confectionery products "should" be expensive (62\% of respondents indicated a high price segment, $32 \%$ of respondents - the price segment is above average, $6 \%$ of respondents - the average price segment);

- the second, exclusive confectionery products are made exclusively of natural and safe ingredients for health (about $89 \%$ of respondents adhere to this position);

- the third, custom-made confectionery cannot be tasteless, as it is made "with love and with soul" by highlevel professionals ( $90 \%$ of respondents fully agree with this statement).

When assessing market alternatives and choosing a confectioner, the consumer assesses the risks that the manufacturer has the ability to influence and to use certain tactical actions to reduce their negative impact on the consumer. Table 3 provides information on the main types of consumer risks in the market under study and possible consumer actions aimed at preventing these risks and tactical actions of the manufacturer, which are recommended to reduce the risk.

Table 3

\section{Consumer risks affecting the market behaviour of consumers of exclusive desserts}

\begin{tabular}{|c|c|c|}
\hline The type of risk and its essence & $\begin{array}{l}\text { Possible actions of the consumer to } \\
\text { prevent the risk }\end{array}$ & $\begin{array}{l}\text { Possible tactical actions of the manufacturer, } \\
\text { which are recommended to reduce the risk }\end{array}$ \\
\hline $\begin{array}{l}\text { Functional } \\
\text { The ordered product may not perform } \\
\text { the basic functional purpose due to a } \\
\text { misunderstanding between the customer } \\
\text { and the manufacturer, due to a lack of clearly } \\
\text { defined technical specification. }\end{array}$ & $\begin{array}{l}\text { Describe all wishes and reservations in } \\
\text { detail, send referrals, draw a sketch as } \\
\text { needed. }\end{array}$ & $\begin{array}{l}\text { To maximize the process of drawing up the } \\
\text { technical task, to offer testing of samples of the } \\
\text { main components of the product, to receive } \\
\text { written confirmation of the requirements for the } \\
\text { future product. }\end{array}$ \\
\hline $\begin{array}{l}\text { Financial } \\
\text { The discrepancy between product price and } \\
\text { quality, price discrepancy and design. }\end{array}$ & $\begin{array}{l}\text { Detailed study of the price, components } \\
\text { of the value of the order, taking into } \\
\text { account the importance and the } \\
\text { necessity of each of them. }\end{array}$ & $\begin{array}{l}\text { Avoiding unjustified overpricing, providing the } \\
\text { appropriate high quality at a set price, informing } \\
\text { the consumer about all the cost components, } \\
\text { about possible additional costs during production }\end{array}$ \\
\hline $\begin{array}{l}\text { Social } \\
\text { A negative assessment by the representatives } \\
\text { of the desired social group, dissatisfaction } \\
\text { with those whom the customer planned } \\
\text { to impress (taste, design, reputation of the } \\
\text { confectionery). }\end{array}$ & $\begin{array}{l}\text { Studying the reputation of the } \\
\text { confectionery through reviews, } \\
\text { comments, recommendations of friends } \\
\text { and experts. }\end{array}$ & $\begin{array}{l}\text { Continuous reputation process by demonstrating } \\
\text { the satisfaction and loyalty of customers who } \\
\text { have already made orders and avoided this risk, } \\
\text { disseminating positive brand information through } \\
\text { engaging social networks, professional circles, } \\
\text { serving social content events to promote the brand. }\end{array}$ \\
\hline \begin{tabular}{l}
\multicolumn{1}{c}{ Time } \\
Significant time spent searching for \\
confectionery, discussing all details and \\
ordering.
\end{tabular} & $\begin{array}{l}\text { Do not waste time searching and } \\
\text { turning to a confectioner, where he } \\
\text { has already made an order or advised } \\
\text { by his friends/colleagues. To trust the } \\
\text { professional and not to discuss every } \\
\text { detail of the order, choose a ready-made } \\
\text { option among the offered }\end{array}$ & $\begin{array}{l}\text { Provide as much information as possible about } \\
\text { the product and pricing policy of the company on } \\
\text { its website (on the page on the social network). } \\
\text { Correctly build communication, develop an } \\
\text { algorithm that can create the technical task for } \\
\text { each order as quickly and efficiently as possible. } \\
\text { Availability of testing of the main components of } \\
\text { the order. }\end{array}$ \\
\hline $\begin{array}{l}\text { Physical } \\
\text { Health damage over the use of ingredients of } \\
\text { poor quality. }\end{array}$ & $\begin{array}{l}\text { Maximize the composition of products, } \\
\text { require quality certificates on the } \\
\text { components of the product. Carrying } \\
\text { out an order in a proven manufacturer's } \\
\text { own experience / based on a positive } \\
\text { feedback from an authoritative expert. }\end{array}$ & $\begin{array}{l}\text { Production of quality products, without the } \\
\text { components harmful to human health. Obligatory } \\
\text { clarification of the fact of the presence of allergic } \\
\text { reactions, intolerance of certain components. } \\
\text { Formation of the image of natural production and } \\
\text { a safe brand. }\end{array}$ \\
\hline
\end{tabular}

Source: compiled by the authors according to the research results 


\section{Post-purchase behaviour}

At the fourth stage of the behavioural process, the consumer directly decides on the order and, on the last, fifth stage, assesses the purchase, based on a sense of satisfaction or dissatisfaction with consumption. Consumer satisfaction is a positive opinion of the consumer as to the suitability of the benefits received from consumption of the product in its expectations, which influences its purchasing decisions.

The key factors that influence the level of consumer satisfaction include: attributes of the product (the quality of the product perceived by the consumer and its price). Mostly, consumers perceive the price of a product as an indicator of its quality: the more expensive it is, the higher quality is. A level of consumers' profit is one of the key factors that influence forming the target audience. Consumers with a low level of profit fully refuse to buy such service on the stage of decision-making about the purchase of dessert or a gift because of the high price, following the position "pastry products shouldn't be so expensive." Consumers with a middle level of profit make a reasonable choice and use possibilities to save on certain components, follow the position "better, but the best," buying a small size of the exclusive product instead of large, that it is offered to in ordinary shops. Consumers with the level of profit higher than middle are less sensible to the price and follow the principle "let it be expensive, but I can pay for exclusive and quality product, and for the impression of the person whom this dessert is intended to." Consumers with a high level of profit are not sensitive to price, they follow the position "price is not important, there are no limitations on a budget, the main point is to get a unique and delicious product, from which we will get a pleasure."

There is also a psychological perception of the price by the buyer, consisting of determining its fairness or injustice, that is, the correspondence of the value received to the amount of money spent.); quality of service; availability of products (presence of goods in the trading network and ease of purchase); latitude of the product range (variety in meeting needs).

If the advertisement or the manufacturer exaggerates both the taste and components of the product, then the expectations of the buyer will be overestimated, and after purchase, it will be either completely satisfied or somewhat disappointed (depends on many factors). The greater the difference between expectations and the actual result, the more disappointed the buyer will be. To avoid this, it is necessary to optimize work with the client, to maximize detail the technical task. But even if the manufacturer, for his part, will make every effort, there is still a risk of dissatisfaction that accompanies individual orders in any sphere, not only in the confectionery industry, since the understanding of these or other concepts may differ from the customer and the performer, because very often the customer himself does not understand what exactly he wants to get as a final result.

According to the results of the study, the following areas of dissatisfaction with target consumers are identified:

- design mismatch with expectations (12\% of respondents);

- unjustified price ( $4 \%$ of respondents);

- dissatisfaction with taste ( $4 \%$ of respondents);

- inconsistency of packaging ( $9 \%$ of respondents);

- complicated order procedure, which requires time and effort ( $8 \%$ of respondents).

We stand on the position that there is a tradition in Ukraine in the consumption of pastries on all holidays and celebrations of personal and domestic character, during a meeting with family and friends. Some celebration or holiday is associated for consumers with something special that creates a stimulus to order exclusive pastries. In this situation, rational reasons of behaviour yield irrational and emotions prevail as the main reason for purchase in the consciousness of consumers.

Modern transformations in consumers' behaviour in the market of pastries are caused by the influence of situational and individual consumer factors, and also factors of the environment. These factors are: the level of profits of the population, growing demand on the ordering of ready dishes and pastries for the celebration of special events, tradition to order exclusive desserts and use in the meal high-quality and natural products, trust to the quality of products of national producers that are basic suppliers for confectionery industry.

After Rokeach value scale, the consumer of exclusive desserts has such terminal values as the happiness of friends and family, life in beauty, health, public confession, interesting life and cognition; and corresponding instrumental consumer's values are high queries, sensitiveness, work, ability to love, rationalism, and braveness. Basic situational factors, which strengthen searching activity of consumer, are: social norms and pressure from referent groups and friends, who make an order of exclusive desserts at every case, and accordingly, expect similar behaviour, the high price of the order, intensive competition and high level of differentiation of products in the market.

Among individual factors that strengthen searching of the consumer activity, it should be noted such factors as high level of consumer's involvement to the process of purchase, his satisfaction from the process of cognition and process of order, tasting of components, development of consumers' own design, orientation on benefits for health from the consumption of the products made from high-quality and natural ingredients. Basic factors that weaken consumer's searching activity are a shortage of time on information search, consumer's preference to a certain brand or producer, the sophisticated process of getting of market 
information because of low communication activity of producers in the market.

To form the positive attitude of target consumers' audience to exclusive desserts and to create their personal interest in the following orders, it is necessary to build such integral character of product/brand/ confectionery that would allow the consumer to get great emotional pleasure and feel confidence in a good and right choice.

\section{Conclusions}

Marketing research on the motivation and behaviour of consumers on the Ukrainian market of exclusive confectionery products showed that these products are characterized by high level of emotional consumer value. The consumer's motivation field consists of the following main motives: motive of satisfaction with the pleasure of relatives and close people; the motive of the product's usefulness and safety of consumption; the motive of belonging to a certain group of people who make individual orders; the motive of freedom and creativity.

Areas of dissatisfaction of target consumers while purchasing exclusive confectionery products are design mismatch expectations, unjustified prices, dissatisfaction with taste, the inconsistency of packaging, complex order procedure, which requires time and effort. The existence of dissatisfaction with consumers regarding the discrepancy between the design of the ordered product and the expectations is predictable. It can be explained by the fact that the consumer usually "idealizes" his order, hopes to get something extraordinary and exceptional. We also note that in this case, the manifestations of the effects of Gestalt psychology are very clearly manifested: the consumer treats an exclusive dessert not as a combination of the ingredients necessary for his production, but he perceives a holistic image of the final product.

In order to reduce potential dissatisfaction of the consumer, companies should try to provide as much as possible clear description of the services offered, try to visualize and materialize the offer to the consumer, thus reducing its perceived risks:

- to provide additional details and standardize the process of obtaining an order, receive written confirmation of the requirements for the future product; - to offer consumer testing of the main components of the order, demonstration of its main components;

- to inform the consumer about all components of the product cost, and possible additional costs;

- to show variants of already existing offers that were previously made and offered to consumers, demonstrate loyalty to customers who have already made an order;

- to use the elements of computer graphics to propose to develop for a customer a "graphic model" of the future dessert for the most possible visualization, to offer different design options, packaging;

- to build such integral character of product/brand/ confectionery, that would allow the consumer to get great emotional pleasure and feel confidence in a good and right choice.

Of course, all these proposals will only work in the case of the production of high-quality products, without the content of harmful components, which will create the image of natural production and a safe brand.

\section{References:}

Blackwell, R.D., Miniard, P.W. \& Engel J.F. (2006). Consumer Behaviour. Thomson/South-Western, 774.

Hansen, T. (2005). Perspectives on consumer decision making: An integrated approach. Journal of Consumer Behaviour, 4(6): 420-437.

Rokeach M. (1973). The Nature of Human Values: Free Press, 438.

Solomon, M.R. (2012). Consumer Behaviour: Buying, Having, and Being. Upper Saddle River, NJ: Pearson Education, 640.

Tsiotsou R.H. \& Wirtz J. (2011). Consumer behaviour in a service context: Edward Elgar Publishing Ltd. UK, 93. Vandecasteele, B. \& Geuens, M. (2011). Motivated Consumer Innovativeness: Concept, Measurement, and Validation. Advances in Consumer Research, Vol.38. [url]: http://www.acrwebsite.org/volumes/15867/volumes/ v38/NA-38.

Wells, V.K. (2014). The influence of behavioural psychology on consumer psychology and marketing. Journal of Marketing Management, 30 (11/12): 1119-1158. [url]: http://dx.doi.org/10.1080/0267257X.2014.929161 